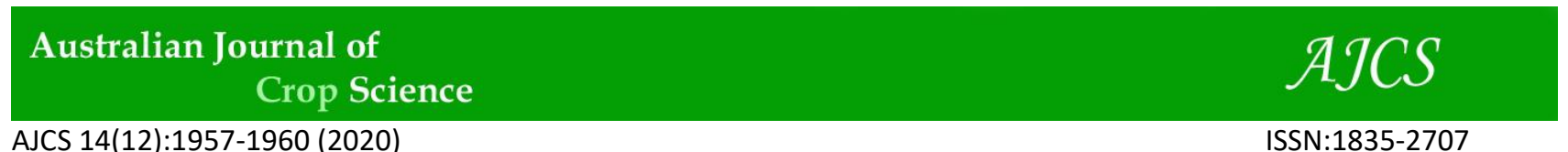

AJCS 14(12):1957-1960 (2020)

ISSN:1835-2707

doi: 10.21475/ajcs.20.14.12.2828

\title{
Optimum plot size for field experiments in sesame
}

Janilson Pinheiro de Assis ${ }^{1}$, Roberto Pequeno de Sousa ${ }^{1}$, Paulo César Ferreira Linhares ${ }^{1}$, Eudes de Almeida Cardoso $^{1}$, Walter Martins Rodrigues ${ }^{2}$, Joaquim Odilon Pereira ${ }^{2}$, Robson Pequeno de Sousa ${ }^{3}$, Aline Carla de Medeiros ${ }^{1}$, Neurivan Vicente da Silva ${ }^{1}$, Anderson Bruno Anacleto de Andrade ${ }^{4}$, Geovanna Alícia Dantas Gomes $^{1}$, Mateus de Freitas Almeida dos Santos ${ }^{1}$, Lunara de Sousa Alves ${ }^{1}$

\author{
${ }^{1}$ Jitirana Research Group, Department of Agronomic and Forestry Sciences, Federal Rural Semi-Arid \\ University, Mossoró, RN, Brazil \\ ${ }^{2}$ Center of Exact and Natural Sciences, Federal Rural Semi-Arid University, Mossoró-RN, 59625-900, Brazil \\ ${ }^{3}$ Computing Department, State university of Paraíba, Campina Grande-PB, 58429-500, Brazil \\ ${ }^{4}$ Plant Protection at the Federal University of Alagoas, Maceió, AL, Brazil
}

*Corresponding author: janilson@ufersa.edu.br

\begin{abstract}
This work aimed to determine the appropriate plot size for field experiments in sesame. We performed a complete randomized block design experiment, using 14 sesame varieties and four replicates. The plots were composed of four rows of $0.8 \mathrm{~m}$ long, spaced $0.6 \mathrm{~m}$ apart, and $0.1 \mathrm{~m}$ between plants. The useful plot area $\left(0.72 \mathrm{~m}^{2}\right)$, which was the two central rows, was divided into 12 basic units with one plant $\left(0.06 \mathrm{~m}^{2}\right)$ each. The measures of sesame production were taken from the useful plot area. The appropriate size of the experimental plot was estimated using the intraclass correlation coefficient method and calculated the detectable difference between treatments. The optimum plot size for evaluation of sesame seed yield was $0.18 \mathrm{~m}^{2}$ (useful area), taking into account the one-row border on the sides. Gains in experimental precision (12\%) were occurred with increments in plot size up to eight basic units $\left(0.48 \mathrm{~m}^{2}\right)$, using five replicates and four or more varieties. The increase in the number of replicates and plot size was more efficient than the increase in varieties number to increase the experimental precision.
\end{abstract}

Key words: Sesamum indicum L, Intraclass correlation coefficient, Experimental precision, Experimental unit.

Abbreviations: $\rho$ _intraclass correlation coefficient method; d_detectable difference between treatments.

Introduction

Sesame (Sesamum indicum L.) is the ninth most cultivated oilseed in the world and its cultivation has great economic potential, due to the possibilities of exploitation, both in the national and international market (Mesquita et al., 2013). World production is estimated at 3.16 million tons, obtained on eight million hectares, with a productivity of $481.4 \mathrm{~kg}$ ha

${ }^{1}$. Brazil is characterized as a small sesame producer with 15 thousand tons produced in an area of 25 thousand hectares and yields around $600.0 \mathrm{~kg} \mathrm{ha}^{-1}$, as it is planted in poor soils (Queiroga et al., 2007). After the fall in cotton production caused by the cotton boll weevil (Anthonomus grandis) cotton's breeding program is developing sesame studies to recommend varieties suitable for cultivation in the Northeast region (Queiroz and Beltrão, 2013). However, for a breeding program success, it is necessary to detect small variations among varieties during experiments, since the tendency is to decrease the difference among the new varieties. The challenge of breeders is to increase the experiment precision, allowing for genetic advances and, consequently, more productive and better quality materials (Silva, 2009). Thus, the execution of high precision experiments requires planning. Therefore, one of the fundamental questions is the appropriate size of the plot or experimental units.

Plot sizes tend to increase with the progress of the breeding program, whereas the more advanced populations need larger plot size for experiments. With the advancement of generations, there is a reduction in the variation between the selected materials, requiring a higher number of plants to detect variation and make the selection. When the increase of plot size does not result in more precision, additional increases in accuracy will be obtained with the use of more replicates (Cargnelutti Filho et al., 2012).

Several factors are involved in choosing the size and shape of experimental plots. Among them, soil heterogeneity is a crucial factor. Thus it is essential to have information about the area, in which the experiments will be carried out (Storck et al., 2016).

Several methods have been used to estimate the optimal plot size, such as the modified maximum curvature method and the linear model segmented with plateau (Ferreira, 2007), either from uniformity assays or experiments that include treatment effects. The intraclass correlation coefficient method stands out among the estimation methods that take advantage of experimental data from 
trials with treatments (Pimentel Gomes, 1984). This method was initially applied to trees, but the theory also applies to annual plants. In this method researcher considers single subplots or lines instead of trees, and the number of unit subplots may be pointed out from the intraclass correlation coefficient, giving the minimum variance of the average in a treatment.

The literature on plot size comprises many cultures and distinct situations. However, no studies were found on the subject for the sesame crops. This work aimed to define the ideal plot size for experiments in sesame using the method proposed by Pimentel Gomes (1984).

\section{Results and discussion}

The analysis of variance (Table 2) calculated the intraclass correlation coefficient $(\hat{\rho})$, and then we estimated the optimal number of useful basic units per plot (Table 3 ).

Significant reductions in $d$ values (gains in experimental accuracy) was occurred with increases size of small plots (Table 4).

The mean square of residue between plots was higher than within the plots (Table 4), showing more variability between plots than among the basic units (BU) within the plot, which resulted in a positive and non-close to zero value $(\hat{\rho}=$ 0.4852 ) of intraclass correlation coefficient $(\hat{\rho})$ for the basic units within plot. This result reveals some correlation between the basic units within the plot, suggesting the use of reasonably small plots, in this case with 3.00 useful BU $\left(0.18 \mathrm{~m}^{2}\right)$.

In a previous experiment, researchers used plots with a useful area of $2.00 \mathrm{~m}^{2}$ to evaluate the growth and productivity of sesame (Mesquita et al., 2013). However, according to our results, the size of the plot could be significantly reduced without compromising the information obtained, since plots with $0.18 \mathrm{~m}^{2}$ of useful area were satisfactory for evaluation of the production of sesame seeds.

When $\rho \leq 0.15$, the solutions are excellent, while low positive values $(\rho \leq 0.15)$ may overestimate the number of useful plants per plot of optimum size. Then, one may need to estimate useful rows as well (Pimentel Gomes, 1988). Silva et al. (2003) confirmed the information above, when performed clonal tests of eucalyptus. They attributed the possibility of inconsistent values to the presence of a single coefficient $(\rho)$, when plot effectively analyzed. Such procedure may underestimate useful plants in the plot, confusing the expected intraclass correlation coefficient in an experiment with a small number of trees and a different degree of competition concerning the plot used in the calculation of $\rho$.

On the other hand, the increase in accuracy was slight with the increase in areas of large plots. Our results corroborate with those obtained by several authors (Henriques Neto et al., 2004; Martin et al., 2004; Brum et al., 2008; Donato et al., 2008; Lúcio et al., 2011; Lúcio et al., 2012; Santos et al., 2012; Sousa et al., 2015).

The highest gains in experimental accuracy (reduction of $d$ values) with increments in plot size were occurred up to 8 BU $\left(0.48 \mathrm{~m}^{2}\right)$. Differences around $20 \%$ between cultivar means can be detected using plots with $4 \mathrm{BU}\left(0.24 \mathrm{~m}^{2}\right), 5$ replicates, and 4 cultivars; or plots with $6 \mathrm{BU}\left(0.36 \mathrm{~m}^{2}\right), 3$ replications and 4 and 8 cultivars. Differences around $15 \%$ can be detected in plots with $4 \mathrm{BU}\left(0.24 \mathrm{~m}^{2}\right), 7$ replicates, and 4 or more cultivars; plots with $6 \mathrm{BU}\left(0.36 \mathrm{~m}^{2}\right), 5$ replicates, and 4 or more cultivars; 8 BU $\left(0.48 \mathrm{~m}^{2}\right), 3$ replicates, and 8 or more cultivars; $10 \mathrm{BU}\left(0.60 \mathrm{~m}^{2}\right), 3$ replicates, and 4 and 8 cultivars; or $12 \mathrm{BU}(0.72)$ and 3 replicates.

The increase in number of replicates was more efficient in reducing the value of $d$ (increase of the experimental accuracy) when compared to the addition in number of cultivars, a fact also shown by Storck, Bisognin and Oliveira (2006), Storck et al. (2007), Donato et al. (2008) and Sousa et al. (2015).

\section{Materials and methods}

\section{Place of study}

The data collection was occurred in an experiment carried out in the city of Barbalha, CE, located 415 meters high, with geographical coordinates $7^{\circ} 18^{\prime} 20^{\prime \prime S}$ and $39^{\circ} 18^{\prime} 9^{\prime \prime} \mathrm{W}$.

We developed an experiment in a randomized block design with 14 sesame cultivars and four replicates. The plots comprised of four rows of 0.8 meters in length each, with an area of $1.92 \mathrm{~m}^{2}(2.4 \mathrm{~m} \times 0.8 \mathrm{~m})$. The row spacing was $0.6 \mathrm{~m}$ and between plants $0.1 \mathrm{~m}$. The plot area consisted of two central rows, eliminating a plant from the ends, making up an area of $0.72 \mathrm{~m}^{2}(1.2 \mathrm{~m} \times 0.6 \mathrm{~m})$. To collect data on the production of sesame seeds, we divided the plot area into 12 basic units, each consisting of one plant in the row, with an area of $0.06 \mathrm{~m}^{2}$.

Based on Pimentel Gomes (1984), the following statistical model was assumed:

$\mathrm{Y}_{\mathrm{ijk}}=\mathrm{m}+\mathrm{c}_{\mathrm{i}}+\mathrm{b}_{\mathrm{j}}+\mathrm{e}_{\mathrm{ij}}+\mathrm{e}_{\mathrm{ijk}}$

where $k=$ number of samples (basic units) per plot, $Y_{i j k}=$ the seed yield in the $\mathrm{K}$ basic unit, of the i cultivar, in $\mathrm{j}$ block; $\mathrm{m}=$ general average; $c_{i}=$ effect of cultivar $i(i=1,2, \ldots$, , cultivars); $b_{j}=$ effect of block $\mathrm{j}(\mathrm{j}=1,2, \ldots, \mathrm{J}$ blocks $) ; \mathrm{e}_{\mathrm{ij}}=$ experimental error between plots; and $\mathrm{e}_{\mathrm{ijk}}=$ experimental error between basic units within the plot $(k=1,2, \ldots, k$ basic units per plot). From the statistical model, the analysis of variance was performed, considering the experimental error between plots (residue (a)) and between basic units within the plot (residue (b)) (Table 1).

${ }^{1} V_{1}=$ mean square of residue between plots; $V_{2}=$ mean square of residue within the plot; $\sigma^{2}=$ variance relative to the experimental error between the basic units within the plot; $\rho=$ intraclass correlation coefficient due to the basic units within the plot.

From the analysis of variance (Table 1), the intraclass correlation coefficient was estimated equalizing the residual mean squares to the respective mathematical expectations, obtaining the following formula:

$\hat{\rho}=\frac{\mathrm{V}_{1}-\mathrm{V}_{2}}{\mathrm{~V}_{1}+(\mathrm{K}-1) \mathrm{V}_{2}}$

Where; $\hat{\rho}=$ estimation of the intraclass correlation coefficient; $V_{1}=$ mean square of the residue between plots; $\mathrm{V}_{2}=$ average square of the residue between basic units within the plot; and $\mathrm{K}=$ number of basic plot units (12 basic units).

Pimentel Gomes (1984) proposes to choose the optimal plot size from plots with $\mathrm{K}$ basic units, complete border, and a double line of useful plants. In this case, the number of 
Table 1. Design of the analysis of variance with $\mathrm{K}$ basic units per plot and mathematical expectation of mean squares.

\begin{tabular}{llll}
\hline Sources of Variation & Degrees of Freedom & $\begin{array}{l}\text { Mean } \\
\text { (MS) }\end{array}$ & Square \\
\hline Blocks & $\mathrm{J}-1$ & & \\
Cultivars & $\mathrm{I}-1$ & $\mathrm{~V} 1$ & $\sigma^{2}[1+(\mathrm{K}-1) \rho]$ \\
Residue (a) & $(\mathrm{J}-1)(\mathrm{I}-1)$ & $\mathrm{V} 2$ & $\sigma^{2}(1-\rho)$ \\
Residue (b) & $\mathrm{Jl}(\mathrm{K}-1)$ & & \\
\hline
\end{tabular}

Table 2. Summary of analysis of variance of the production of sesame seeds.

\begin{tabular}{lcc}
\hline Sources of Variation & Degrees of Freedom & Mean Squares \\
\hline Blocks & 3 & $232.66^{* *}$ \\
Cultivars & 13 & $800.43^{* *}$ \\
Residue (a) & 39 & 688.52 \\
Residue (b) & 616 & 55.94 \\
\hline $1_{* *}$ significant at 1\% probability according to the F test.
\end{tabular}

Table 3. Optimum plot size in basic units (BU) for the production of sesame seeds, estimated by the intraclass correlation coefficient method ${ }^{1}$.

\begin{tabular}{|c|c|c|c|}
\hline $\begin{array}{l}\text { Mean Square of Residual } \\
\text { Between Parcels }\end{array}$ & $\begin{array}{c}\text { Mean Square of Residual } \\
\text { Inside Plot }\end{array}$ & $\begin{array}{c}\text { Intraclass Correlation } \\
\text { Coefficient }(\widehat{\boldsymbol{\rho}})\end{array}$ & $\begin{array}{c}\text { Optimum Number of } \\
\text { Useful Basic Units per Plot } \\
\text { (k) }\end{array}$ \\
\hline 688.52 & 55.94 & 0.4852 & 3.00 \\
\hline
\end{tabular}

Table 4. Difference between averages of two cultivars (\% of the mean) expected to be detected in the evaluation of the sesame production, considering different plot sizes (BU), cultivar numbers and replicates, estimated by the Hatheway method ${ }^{1}$.

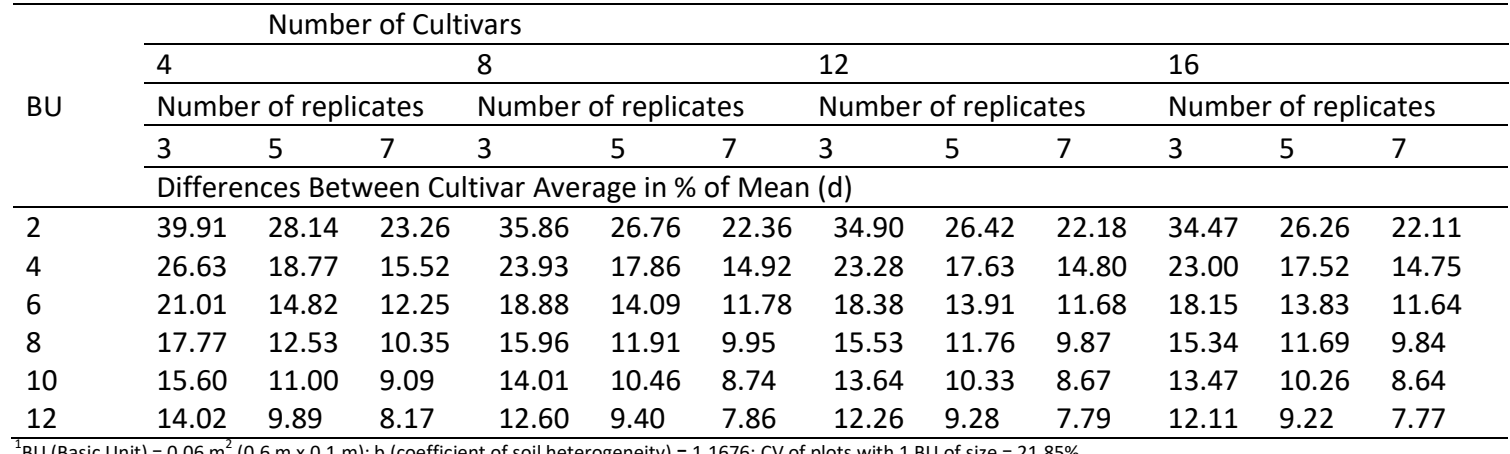

useful basic units (k) was: a) If $\hat{\rho} \geq 0.50$, so $k=2$; b) if $0<\hat{\rho}<0.50$, use the equation:

$$
\mathrm{k}=2 \sqrt{\frac{(1-\hat{\rho})}{\hat{\rho}}}
$$

Where; $k$ is a natural number or one of the values of $k$ natural numbers even closer to the value of the root; $c)$ when $p<0$, k should be as large as possible, compatible with a reasonable number of degrees of freedom for the residue (usually at least $10 \mathrm{df}$ ).

The difference between two cultivar averages were expressed as a percentage of the mean expected to be detected was calculated using the Hatheway (1961) method:

$\mathrm{d}=\sqrt{\frac{2\left(\mathrm{t}_{1}+\mathrm{t}_{2}\right)^{2} \mathrm{CV}_{1}^{2}}{\mathrm{rX}^{\mathrm{b}}}}$

Where; $t_{1}$ is the critical value of $t$ in Student's distribution at the $5 \%$ level, $t_{2}$ is the $t$-value from the table at level 2(1-P), $P$ the probability of obtaining a significant result $(80 \%), \mathrm{CV}_{1}$ the coefficient of variation of plots with $1 \mathrm{BU}$ (basic unit), $r$ the number of repetitions, and $b$ the coefficient of soil heterogeneity, obtained after the linearization of the equation of Smith (1938):

$\mathrm{V}_{\mathrm{x}}=\frac{\mathrm{V}_{1}}{\mathrm{X}^{\mathrm{b}}}$
Where; $V_{x}$ is the variance per unit area of plots made up of $\mathrm{X} \mathrm{BU}$ of size, $\mathrm{V}_{1}$ is the variance of the plots constituted of 1 $B U$, and $X$ is the number of $B U$ that make up the plot (plot size). The value of $b$ and CV1 were estimated in each of the 56 plots (14 cultivars and four replicates), using the $12 \mathrm{BU}$ of the plot area.

To estimate the detectable difference (d), we experimented with a randomized block design comprising $4,8,12$, and 16 cultivars; 3, 5, and 7 replicates; and parcel sizes of 2, 4, 6, 8, 10 , and $12 \mathrm{BU}$.

\section{Conclusions}

The optimum plot size for evaluating the yield of sesame seeds was $0.18 \mathrm{~m}^{2}$ (useful area), considering a one-row border on the sides. This size is smaller than the one generally used in research with the sesame crop $\left(2.00 \mathrm{~m}^{2}\right)$. The highest gains in experimental precision (12\%) with increments in plot size was occurred up to 8 Basic Units $\left(0.48 \mathrm{~m}^{2}\right)$, using 5 replicates, and 4 or more cultivars.

The Increase in number of replicates and plot size were more efficient to increase experimental accuracy than the increase in the number of cultivars. 


\section{Acknowledgements}

Special thank the Jitirana (Merremia aegyptia L.) Research Group committed to the study of spontaneous species of the Caatinga Biome as fertilizer source and the Department of Agronomic and Forestry Sciences the Federal Rural SemiArid University (UFERSA), for the support in the conduction of the project.

\section{References}

Brum B, Lopes SJ, Stork L, Santos VJS, Benz V and Lovato C (2008) Tamanho ótimo de parcela para ensaios com sorgo granífero em duas épocas de semeadura. Ciência Rural. 38: 315-320.

Cargnelutti Filho A, Marchesan E, Silva LS and Toebe M (2012) Medidas de precisão experimental e número de repetições em ensaios de genótipo de arroz irrigado. Pesquisa Agropecuária Brasileira. 47: 336- 343.

Donato SLR, Siqueira DL, Silva SO, Cecon PR, Silva JA And Salomão LCC (2008) Estimativas de tamanho de parcelas para avaliação de descritores fenotípicos em bananeira. Pesquisa Agropecuária Brasileira. 43: 957-969.

Ferreira DF (2007) Use of computational resources. Lavras: Federal University of Lavras, 157p.

Hatheway EH (1961) Convenient plot size. Agronomy Journal. 53: 279-280.

Henriques Neto D, Sediyama T, Souza MA, Cecon PR, Yamanaka CH, Sediyama MAN and Viana AES (2004) Tamanho de parcelas em experimentos com trigo irrigado sob plantio direto e convencional. Pesquisa Agropecuária Brasileira. 39: 517-524.

Lúcio AD, Haesbaert FM, Santos D and Benz V (2011) Estimativa do tamanho de parcela para experimento com alface. Horticultura Brasileira. 29: 510-515.

Lúcio $A D$, Haesbaert FM, Santos D, Schwertner DV and Brunes RR (2012) Tamanhos de amostras e de parcelas para variáveis de crescimento e produtivas de tomateiro. Horticultura Brasileira. 30: 660-668.

Martin TN, Storck L, Lopes SJ, Santos PM, Carvalho MP and Damo HP (2004) Definição de plano experimental para comparações de cultivares de milho em áreas limitadas. Revista Brasileira de Milho e Sorgo. 3: 325-332.

Meir VD, Lessman KJ (1971) Estimation of optimum field plot shape and size for testing yield in Crambe abyssinica Hochst. Crop Science. 11: 648-650.
Mesquita JBR, Azevedo BM, Campelo AR, Fernandes CNV and Viana TVA (2013) Crescimento e produtividade da cultura do gergelim (Sesamum indicum L.) sob diferentes níveis de irrigação. Irriga. 18: 364-375.

Pimentel Gomes F (1988) Novos aspectos do problema do tamanho ótimo das parcelas em experimentos com plantas arbóreas. Pesquisa Agropecuária Brasileira. 23: 5962.

Pimentel Gomes F (1984) O problema do tamanho das parcelas em experimentos com plantas arbóreas. Pesquisa Agropecuária Brasileira. 19: 1507-1512.

Queiroga VP, Arriel NHC, Beltrão NEM, Silva ORR, Gondim TMS, Firmino PT, Cartaxo WV, Silva AC, Vale DG and Nóbrega DA (2007) Cultivo ecológico do gergelim: alternativa de produção para comunidades de produtores familiares da Região Semiárida do Nordeste. Campina Grande: Embrapa Algodão. 54p. (Embrapa Algodão. Documentos, 171).

Queiroz NL and Beltrão NEM (2013) Melhoramento genético e cultivares. IN: Beltrão NEM, Ferreira LL, Queiroz NL, Tavares MS, Rocha MS, Alencar RD and Porto VCN 2013. (Org.) O gergelim e seu cultivo no semiárido brasileiro. Natal: IFRN, 225p. Cap. 5.

Santos D, Haesbaert FM, Lúcio AD, Storck L and Cargnelutti Filho A (2012) Tamanho ótimo de parcela para a cultura do feijão-vagem. Revista Ciência Agronômica. 43: 119-128.

Silva JR (2009) Tamanho de parcela e efeito de bordadura em experimentos com meloeiro. 142f. Tese (Doutorado em Fitotecnia) - Universidade Federal Rural do SemiÁrido, Mossoró-RN.

Silva RL, Xavier A, Leite HG and Pires IE (2003) Determinação do tamanho ótimo da parcela experimental pelos métodos da máxima curvatura modificado, do coeficiente de correlação intraclasse e da análise visual em testes clonais de eucalipto. Revista Árvore. 27: 669-676.

Smith HF (1938) An empirical law describing heterogeneity in yields of agricultural crops. Journal Agricultural Science 28: 1-23.

Sousa RP, Silva PSL, Assis JP, Silva PIB, Silva JCV (2015) Optimum plot size for experiments with the sunflower. Revista Ciência Agronômica. 46: 170-175.

Storck L, Bisognin DA, Oliveira SJR (2006) Dimensões dos ensaios e estimativas do tamanho ótimo de parcela em batata. Pesquisa Agropecuária Brasileira. 41: 903-909.

Storck L, Garcia DC, Lopes SJ and Estefanel V (2016) Experimentação vegetal. 3. ed. Santa Maria: UFSM. 198p.

Storck L, Ribeiro ND, Lopes SJ, Cargnelutti Filho A, Carvalho $M P$ and Jost E (2007) Persistência do plano experimental em ensaios de avaliação de germoplasma elite de feijão. Ciência Rural. 37: 1549-1553. 